\title{
Gedanken und Thatiachen.
}

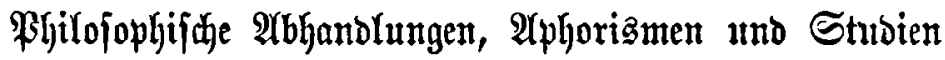

bon

Otto eiebmann.

3reiter Band, 3reitea Şeft.

Strä̧burg.

Berlag von $\mathfrak{R} a \mathfrak{l} \mathfrak{3}$. Trubarer.

1901.

Seubrud 1925 


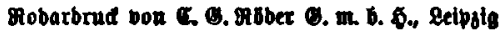

